\title{
Nurses' practice in quilombola communities: an interface between cultural and political competence
}

\author{
Prática do enfermeiro em comunidades quilombolas: interface entre competência cultural e política \\ Práctica de enfermería en comunidades de quilombolas: interfaz entre competencia cultural y política
}

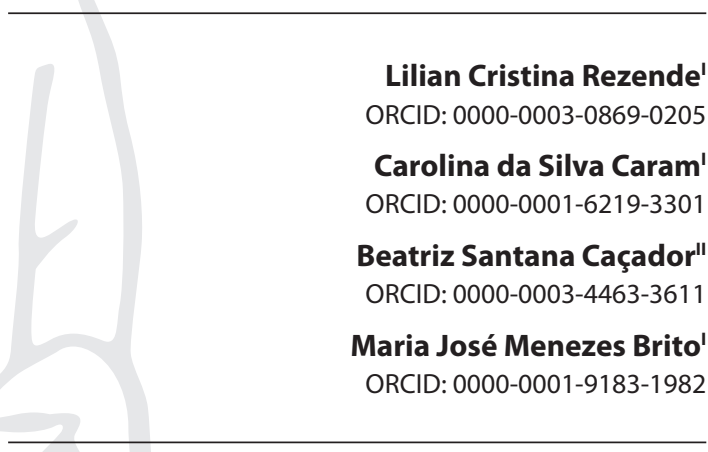

'Universidade Federal de Minas Geras. Belo Horizonte, Minas Gerais, Brazil. "Universidade Federal de Viçosa, Viçosa, Minas Gerais, Brazil.

How to cite this article: Rezende LC, Caram, CS, Caçador BS, Brito MJM. Nurses' practice in quilombola communities: an interface between cultural and political competence. Rev Bras Enferm. 2020;73(5):e20190433. doi: http://dx.doi.org/10.1590/0034-7167-2019-0433

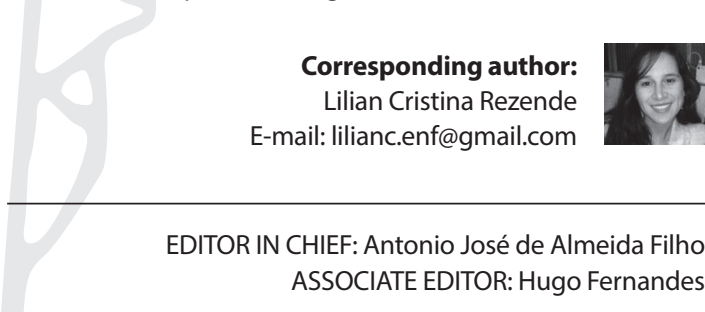

Submission: $13-08-2019$

Approval: 17-12-2019

\section{ABSTRACT}

Objectives: to understand Family Health Strategy nurses' practices in the context of quilombola communities with an interface for cultural and political competences. Methods: a single integrated, qualitative case study carried out on seven Family Health Strategies located in the Metropolitan Region of Belo Horizonte, state of Minas Gerais. Seven nurses and 59 quilombolas participated. Data were collected through individual interviews with nurses, collective interviews with quilombolas and observation. For analysis, the thematic content analysis was adopted. Results: the results revealed structural and territorial problems, which are configured as barriers for professional-user encounter as well as for professional practice performance. Final Considerations: it is necessary that Family Health Strategy nurses, based on political and cultural competences, create strategies that minimize the difficulties found in the implementation of health actions directed to quilombolas. Such strategies anchored in inclusive public policies.

Descriptors: Nursing; Primary Health Care; African Continental Ancestry Group; Cultural Competency; Professional Competence.

\section{RESUMO}

Objetivos: compreender a prática do enfermeiro na Estratégia Saúde da Família no contexto de comunidades quilombolas com interface para as competências cultural e política. Métodos: estudo de caso único integrado, qualitativo, realizado em sete Estratégias Saúde da Família localizadas na Região Metropolitana de Belo Horizonte, MG. Participaram 7 enfermeiros e 59 quilombolas. Os dados foram coletados por meio de entrevistas individuais com enfermeiros, entrevistas coletivas com quilombolas e observação. Para a análise, adotou-se a análise temática de conteúdo. Resultados: os resultados revelaram problemas estruturais e territoriais, os quais se configuram como barreiras para a efetivação do encontro profissional-usuário, bem como para a efetivação da prática do profissional. Considerações Finais: é necessário que o enfermeiro da Estratégia Saúde da Família, alicerçado por competências políticas e culturais, crie estratégias que minimizem as dificuldades encontradas na concretização das ações de saúde direcionadas para os quilombolas. Tais estratégias ancoradas em políticas públicas inclusivas.

Descritores: Enfermagem; Atenção Primária à Saúde; Grupo com Ancestrais do Continente Africano; Competência Cultural; Competência Profissional.

\section{RESUMEN}

Objetivos: comprender la práctica de las enfermeras en la Estrategia de Salud Familiar en el contexto de las comunidades de quilombolas con una interfaz para las competencias culturales y políticas. Métodos: estudio de caso cualitativo integrado único realizado en siete Estrategias de Salud Familiar ubicadas en la Región Metropolitana de Belo Horizonte, Minas Gerais. Participaron 7 enfermeras y 59 quilombolas. Los datos fueron recolectados a través de entrevistas individuales con enfermeras, entrevistas colectivas con quilombolas y observación. Para el análisis, se adoptó el análisis de contenido temático. Resultados: los resultados revelaron problemas estructurales y territoriales, que se configuran como barreras para la realización del encuentro profesional-usuario, así como para la realización de la práctica profesional. Consideraciones Finales: es necesario que la enfermera de la Estrategia de Salud Familiar, basada en competencias políticas y culturales, cree estrategias que minimicen las dificultades encontradas en la implementación de acciones de salud dirigidas a las quilombolas. Dichas estrategias ancladas en políticas públicas inclusivas. Descriptores: Enfermería; Atención Primaria de Salud; Grupo de Ascendencia Continental Africana; Competencia Cultural; Competencia Profesional. 


\section{INTRODUCTION}

The Brazilian Unified Health System (SUS - Sistema Único de Saúde) has gaps between the prescribed and the real dimensions. In spite of the complexity and relevance of organizational, structural and financial challenges, it is necessary to pay attention to the dimension and complexity of the micropolitical space of practice in what concerns the materialization in the daily life of the consolidation of equity and comprehensiveness principles.

In the Family Health Strategy (FHS), nurses' practices deserve special attention due to the strategic role of this professional in the identification of the population's health needs and in the realization of the meeting between professionals and patients, families and communities ${ }^{(1-2)}$. Regarding the role of nurses, the several care dimensions are evident, as a power to coordinate practices, enabling equity and comprehensiveness, including the prevention of injuries, damage protection, recovery and treatment at the individual and collective levels ${ }^{(3)}$. It is also worth highlighting the direction of nurses' actions towards the reorganization of services, focusing on health surveillance, based on the concept of health constituted by social relationships, in the effective meeting between patient and professionals and focused on the population needs ${ }^{(4-5)}$.

Practice at FHS requires apprehension of the sociocultural context of the individual and the community, often permeated by situations of social vulnerabilities and cultural singularities. Among the settings of nurses' work, quilombola (A quilombola is an Afro-Brazilian resident of quilombo settlements first established by escaped slaves in Brazil) communities are presented, whose particularities are linked to their historical trajectory and African ancestry ${ }^{(6)}$. In addition to their own historical trajectory, quilombola communities establish specific territorial relations, with a presumption of black ancestry, related to resistance to historical oppression ${ }^{(4)}$. This population contingent suffers as a result of a historical and social process that impacts on their health conditions and, consequently, on health indicators, placing them in a socially vulnerable situation ${ }^{(7)}$.

According to data from the Brazilian Institute of Geography and Statistics (IBGE - Instituto Brasileiro de Geografia e Estatística), released in 2016, 54.9\% of the Brazilian population was considered black or mixed-race ${ }^{(8)}$. Despite constituting a majority in the country, this population is considered sociologically minority due to the precarious living and health conditions ${ }^{(7)}$. In this regard, systematic evidence indicates that black people have a higher incidence of disease and die earlier in all age groups ${ }^{(9)}$. There are chronic diseases, such as arterial hypertension, whose prevalence is twice as high in black individuals, which is strongly associated with lower social strata, doubly worsening black population vulnerability ${ }^{(10)}$.

The considerations presented lead us to reflect on the relevance of nurses' performance in quilombola communities, considering their social role and commitment to this community. For the effectiveness of their practice, it is essential that nurses recognize the socio-cultural arrangements of the territory, the situations of vulnerability of the families, the difficulties of access to services, the local specificities, the indicators and the parameters established for the territory ${ }^{(4)}$. Therefore, it is necessary to contextualize nurses' practices in the midst of social vulnerabilities with theoretical approaches that consider the particularities of social minorities in line with their reality.

With regard to epistemological framework for approaching the subject in focus, feminist ethics appropriation stands out ${ }^{(11)}$, as it allows us to project the look towards the development of cultural and political competences. The actions of nurses and staff are based on equity and comprehensiveness principles and carried out in line with the reality and needs of quilombola communities. It is emphasized that the feminist ethics emerges from reflections on social minorities and seeks to encourage actions that eliminate the various forms of oppression and privileges arising from hegemonic hierarchies ${ }^{(11)}$.

Cultural competence involves three dimensions: sensitivity to other people's cultural beliefs, practices and knowledge, as well as their expectations and origins; raising awareness for developing strategies to improve access to health care and; eliminating structural barriers for minorities ${ }^{(12)}$. It is, therefore, about the development of skills that allow the recognition of the values of users, considering the differences in access to health services and the disparities between minorities and the majority population $^{(11-13)}$.

Political competence is developed in the social context and requires the positioning of political agents with a questioning attitude, capacity for reflection and understanding of social reality in its concreteness and understanding of its power to transform this reality. Political competence is present in professionals capable of expressing their own judgment and understanding the countless needs of individuals and communities, taking as a focus the valorization of people's way of being and living ${ }^{(11)}$.

In view of the considerations presented, it is assumed that nurses' practices at FHS requires the development of specific skills that take into account cultural and social diversity, offering answers to the challenges that arise.

Thus, the question is: how have nurses' practices been configured in quilombola communities? How have nurses mobilized cultural and political skills in their practice?

\section{OBJECTIVES}

To understand FHS nurses' practices in the context of quilombola communities with an interface for cultural and political competences.

\section{METHODS}

\section{Ethical aspects}

The research complied with the requirements recommended by Resolution 466/12 of the Brazilian National Health Board (Conselho Nacional de Saúde). It was approved by the Research Ethics Committee of the Federal University of Minas Gerais (Universidade Federal de Minas Gerais-UFMG) (Opinion 2,285,857) and authorized with a Consent Term by the Municipal Health Departments of the cities. The Informed Consent Term was read and signed by the participants who voluntarily participated in the study and were aware of the possible discomforts, risks and benefits. To 
ensure anonymity, nurses' individual interviews were given the name "NUR", followed by the random number from 1 to 7 and the collective interviews with quilombolas the name "QUILOMBO", followed by the random number from 1 to 7 to represent the number of performed groups.

\section{Type of study}

This is a qualitative research, considering the search for the understanding of subjective aspects of events that happen in everyday life. Such an approach enables empirical discoveries, elucidating the participants' worldview ${ }^{(14)}$. Qualitative research is able to incorporate meaning, intentionality, relationships and social structures as inherent to acts, the latter being taken both in its advent and in its transformation and in the significant human constructions ${ }^{(14)}$.

An integrated single case study as a methodological design was used, with the ten quilombola communities visited forming the units of analysis ${ }^{(15)}$. The defined case was FHS nurses' practices in quilombola communities, considering the socio-cultural context in which they are inserted, as well as the individual ethical-moral values typical of daily practice. It is assumed that the boundaries between the case and the context are not clearly evident, which makes understanding the phenomenon relevant considering the relevant contextual conditions ${ }^{(15)}$.

The theoretical proposition adopted is based on the feminist ethics proposed by Margaret Urban Walker (1998)(11), with a focus on the analytical approach of the cultural and political competences of nurses to act in a way that is congruent with the reality of quilombola communities.

\section{Methodological procedures}

\section{Study setting and participants}

The setting of this study was the FHS where quilombola communities certified by Fundação Cultural Palmares (FCP), based in the Metropolitan Region of Belo Horizonte (RMBH - Região Metropolitana de Belo Horizonte), in the state of Minas Gerais, are registered. At the time of the approval of the present investigation, there were 278 quilombola communities certified by FCP in Minas Gerais, of which 10 were based in the RMBH. Therefore, the investigation covered the 10 quilombola communities certified by FCP in the $\mathrm{RMBH}$, with four urban communities and six rural communities. Regarding urban communities, three are located in Belo Horizonte (Luízes, Manzo Ngunzo Kaiango and Mangueiras quilomba Community) and one in Contagem (Arturos quilombola Community). Among the rural communities, three are located in Brumadinho (Sapé, Marinhos and Ribeirão quilombola Community), two in Jaboticatubas (Mato do Tição and Açude quilombola Community) and one in Pedro Leopoldo (Pimentel quilombola Community). Attention should be drawn to the fact that urban communities are located in proximity to the FHS, which is not the case for rural communities, whose distance corresponds to an average of $14 \mathrm{~km}$. In this regard, it is highlighted that a community of Jaboticatubas was located $30 \mathrm{~km}$ away from the FHS. Geographical distance is significant in relation to the access of the quilombola population to health services, since these are roads without paving, in precarious conditions of conservation and without regular public transport.

The participants in this study were nurses from the FHS team who work with quilombola communities in the territory where they work. The inclusion criterion for professionals was to have been working at FHS for at least 6 months in the service to the quilombola community. Three nurses from Belo Horizonte participated in the research, one from Contagem, one from Brumadinho, one from Jaboticatubas and one from Pedro Leopoldo, comprising seven nurses in total. Quilombola residents registered with the FHS were also participants in the survey. The inclusion of these residents is justified by the fact that the practice constitutes a social activity based on cooperation among subjects principles, with legitimacy by the recipient ${ }^{(16)}$. For quilombola residents, the inclusion criteria were being of age, being residents of quilombola communities and being registered with the FHS. Fifty-nine quilombolas belonging to Arturos, Marinhos, Ribeirão, Sapê, Açude, Mato do Tição, Pimentel Communities accepted to participate.

\section{Data collection}

Data collection took place in the period between February and June 2018 after contact and scheduling with the unit managers and the leaders of quilombola communities. The study was established according to COREQ guidelines. The strategies for data collection were observation, individual interview with nurses and collective interview with communities residents, meeting the premise of triangulation of data collection in case studies ${ }^{(15)}$.

Observation was carried out in health units and quilombola communities, focusing on the activities developed by nurses in the context of each quilombola community.

Individual interviews with nurses were carried out at FHS, whose scheduling was previously done, according to the dates and times provided by professionals. The place where the interviews were conducted was reserved at the health unit itself, indicated by participants, preserving their privacy. The average interview time was 30 minutes and the nurses answered questions regarding their knowledge about the community, public policies aimed at serving the black population, the practice in the FHS in the community and, finally, about the obstacles and daily facilities.

The groups that made up the press conference were composed of residents of quilombola communities, registered with the FHS, who were willing to participate voluntarily in the investigation. The invitation to the communities was made by the leader of each community, after a previous conversation with the researchers responsible for the study and mediated by the Community Health Agents. The collective interviews took place in the community itself, in previously agreed places and according to participants' availability. The guiding questions focused on the meaning of living in the quilombola community, the health care received by the community and the difficulties faced, in view of the community particularities. Seven meetings were held for press conferences, one in each community, with the exception of the three communities in Belo Horizonte that refused to participate in this stage of the investigation. The number of participants per group was eight people in the Sapê Community; eight in 
the Ribeirão Community and seven in the Marinhos Community, in the municipality of Brumadinho; eight in the Pimentel Community, in Pedro Leopoldo; seven in the Arturos Community, in Contagem. In Jaboticatubas, there were 11 people in the Mato do Tição Community and 10 in the Açude Community, totaling 59 people from the communities participating in the study. The average time for group interviews, per group, was 40 minutes. The testimonies were recorded and transcribed in full.

\section{Data analysis}

For data analysis, the thematic content analysis technique was used, which consists of a set of communication analysis techniques ${ }^{(17)}$. This type of analysis aims to achieve the essence of reports by carrying out organized procedures with the aim of describing message content. For this purpose, data were organized around three interrelated poles: 1) pre-analysis; 2) material exploration and treatment of the results; 3 ) inference and interpretation. With regard to the research's documentary corpus, it was constituted by transcripts of interviews with nurses, interviews with quilombolas and Observation Notes (ON), from the field diary. These documents were inserted in the ATLAS.ti ${ }^{\circ}$ 7.0 software, composing a hermeneutic unit with 14 documents in pdf format. It is noteworthy that the software contributed to the information management and text coding, being used as an operational tool that favored indexing, searching and theorizing ${ }^{(18)}$.

\section{RESULTS}

This study pointed out the existence of barriers in the FHS daily routine, hindering the development of the practice by nurses, mainly in the effectiveness of care for quilombola communities. Among them, high demand, overload of work, lack of infrastructure to develop activities for the prevention of health problems and health promotion, as well as for nursing consultations at different stages of life, stood out.

A particularity pointed out in this study was the geographical distance between rural communities and the health unit. It is configured in the researched setting as FHS, directly impacting the quality of access and care. The aspects pointed out interfere in the nurse's practice, who, due to service intense demands, exercise their activities in a little reflexive way, without questioning, therefore, the potential of their practice as a transforming action, potentiating situations of vulnerability already experienced by quilombola communities.

In this respect of rural communities, the participant NUR1 highlighted the geographical distance of health units in rural areas in relation to the communities, as well as the scarcity of transport, which is considered a difficult element for the access of users and professionals. Thus, in some units the service started to happen every fortnight, with consequences for the community, as evidenced:

We have great difficulty in serving the transport communities. We are divided into three regions, that of the farms. The car is available half-time, once a week, including the "quilombola", which is in the region of the farms. They are all very far from the unit, and then we prioritize what gives. Without the car neither CHAs will go, because it is far, there is no way to go. Visits, they do on Tuesday, when you have a car. (NUR1)

There at [name of the place], there are a lot of people to serve, some twenty or more. The service is only in the morning, it is very crowded there, and it is only every 15 days, do you think? The doctor and the technician come, the staff complains a lot, there are people who go early, and stay there waiting! (QUILOMBO4)

We have an access problem; we only have one car to get around. Here things are more difficult to get, sometimes even a computer, a printer, I feel that the countryside is more affected at this point. We are further away from the headquarters, there is a dirt road, the lack of the community, to go to the municipality's headquarters you have to take a bus and it is $28 \mathrm{~km}$ from here. (NUR2)

Except that for us to have access is very complicated, everything is further and more difficult. (QUILOMBO7)

Difficulties in access resulting from geographical distance compromise the nurse-patient/family meeting effectiveness. In these situations, nurses focus their practice on the demands of attending to acute situations, as they are unable to act more closely to the population in rural areas. Considering the quilombo's situation of social vulnerability, professionals need to be with the community to understand their real needs in order to reduce existing racial disparities. The situation identified in the present study opens space for the expansion of inequality that falls on the quilombola population.

It was observed that the health units visited in the urban region were full and with difficulty in relation to the availability of rooms for care, requiring relocation of activities to meet spontaneous demand. In addition, inadequate infrastructure and work overload made the operation of health education groups in the units visited (ON) unfeasible.

Lack of physical space and accumulation of activities that are not characteristic of nurses, concomitant with the high demand at FHS, were also cited by nurses as barriers to their practice.

We have a serious problem here that is physical space, mainly we nurses are a bit of a corner. In the morning, sometimes, I manage to stay in the gynecology office. In the afternoon, every day I am in a room, there is no space for health promotion groups, we miss many opportunities because of the physical space. (NUR7)

At the reception we see 50 patients, this is daily. On average, about 30 patients are to schedule an appointment because they missed the appointment. They are very easy to miss appointments. There! You schedule the appointment! Make referral to specialist! I didn't need that; I could have a folder there at the reception and a person who needs to reschedule leaves the referral to be discussed later with the team. And then there is a high-pitched call, then you will answer the high-pitched call, it takes a long time and you don't have much time to answer, and a patient fight, cursing, because it is taking too long. (NUR5)

Our job is difficult. In the reception it is more difficult. We receive the spontaneous demand and do a screening, it is not a nursing consultation, you will listen to the complaint and according to the 
complaint you direct whether you are going to consult today or not. So, sometimes, people see us as the one who will choose whether to consult or not, sometimes you take statements like that. (NUR7)

The speech of NUR5 reveals that, during the reception, the care provided is aimed at rescheduling a missed appointment with a specialist. This situation is a need that has been shown in the daily routine of family health and that requires the involvement of nurses in the search for a solution (ON). NUR7 points out that triage translates, in the population's imagination, into choices made randomly by nurses, for medical consultations. Therefore, there is a weakening of nurses' practices, which distances themselves from the possibility of building care that incorporates the meeting as a potential for apprehending the user's needs and strengthening the bond.

Reinforcing the infrastructure weaknesses already mentioned, NUR5 refers that the demand for work in the unit consumes him in such a way that he is unable to project his practice in the quilombola community, even saying that he does not know it. This situation is confirmed by a user who claims not to know the nurse.

I have no practice in the quilombo. I don't know the "quilombola" community, even a resident there came to talk to me, because there are many pregnant teenagers. She would very much like me to do social work there, a nursing job. But I'll be honest, I couldn't even think about what I could do there, because I'm not doing it, every day is a different job that I have to do here, and I end up with a huge demand. (NUR5)

I don't know the nurse. I met her when I was doing prenatal care. I know, because of my mother who is visually impaired and has high blood pressure and then she receives a visit from the nurse. (QUILOMBO1)

The distancing of nurses from users promotes the lack of social recognition of this professional, compromising practice legitimation. Consequently, practice does not generate resonance for quilombola communities, weakening the scope of principles such as equity and comprehensiveness of health care.

The dynamics experienced by nurses at FHS potentiates the reductionist practice, making it impossible for the professional to provide assistance as a power to coordinate care practice and effectively improve the population's health. NUR5 reports that he does not perform consultations that could be nursing and the care is performed by the medical professional.

I have a very large population in my region, so I have more space on the agenda of the psychologist, the psychiatrist, the pediatrician, the gynecologist, the clinician. So, I can't serve and I'm trying to fit patients for these professionals. The pediatrician does childcare, the gynecologist does preventions and prenatal consultations. (NUR5)

The nurse comes, looks at the pressure and asks how it is. Check the medicines, if they are in order. It is very difficult for nurses to serve; the appointment is more with the doctor. Equal preventive, prenatal, does not go through the nurse, only through the doctor. It passes by the nurse when we get there, the nurse who makes the first reception. She checks the pressure, then you go to the doctor. (QUILOMBO7)
Considering the quilombola population, considered a socially vulnerable minority, due to the historical, economic and social factor, nurses pointed out that the biggest challenge is to reach the user and learn their values and beliefs in order to conduct care equally and culturally relevant. Although participants are aware of territory vulnerability, promoting a practice centered on meeting and planning actions for the organization of services as a bridge for access to the black population is a distant reality.

The nurse takes over many functions. There is the supervision of assistants, technicians, CHAs, unit sectors, we are responsible for the pharmacy, the vaccine, the dressing, the observation room, so we have to take care of that too. I have four CHA, my population is all high risk, immense social vulnerability, a lot of violence, even misery. I also have to solve that paperwork, the maps that have to be closed every month, the spreadsheets that have to be filled out and charged for CHA production, anyway. (NUR7)

Understanding the social, political and cultural context with a careful look at the fragile situations that make up society is essential for the performance of nurses' practices. For this, the development of communication skills culminates in reducing the gaps that permeate reality in the FHS. It requires a space that is appropriate for care, providential for the creation of bonds, strengthening a co-responsible practice in which joint decisionmaking is exercised in the critical capacity for interventions in the social environment and work spaces.

To promote care capable of integrating FHS protagonists, QUILOMBO4 points out a possible strategy such as meetings and conversation circles to discuss the problems encountered.

I think there should be a conversation with the staff, to expose things. Like us here. The medical center could offer that, a conversation, a meeting. Join with the health team to find out what the team thinks and what to bring to the community, to try to see a way to improve, right? (QUILOMBO4)

The complexity presented in the daily life of the FHS, in this study, affects not only the practical quality performed, but also the feeling of suffering in the professional who is faced with a reality that they cannot transform to be truly nurses.

In fact, I'm a little frustrated here, it's very difficult for you to provide assistance. Here you put out the fire and do a lot more administrative work than even nursing, assistance, because there is no professional to do these administrative services, I was making calls for specialized consultation, right now. I call a patient to sort out a patient issue, I schedule exams, this I could be going over. [...] what I know, are the demands that pass here, every day is exhausting. I can't do childcare, I don't have time for prenatal care, I can only serve one a day, I can't serve anymore. I do not manage to evolve my patients during the day, at the reception in the morning, put it in the notebook and evolve in the afternoon. [...] every hour a user comes with a demand, a demand for you to solve, It turns out that it is not even the focus that you should do at FHS. It is very complicated. I get a little stressed from overwork and there is still a financial issue that ends up influencing everything in your life. (NUR5)

I am in a very tired phase. I'm a little worn out, a little unmotivated, perhaps due to the accumulation of service. (NUR7) 


\section{DISCUSSION}

The present study showed weaknesses in the performance of FHS nurses' practices in assisting quilombola communities, distancing them from caring for socially vulnerable communities, as recommended by SUS principles. The weaknesses presented in the development of nurses' practices in this study were high demand, work overload, lack of infrastructure to develop health prevention and health promotion activities, as well as for nursing consultations at different stages of life. Such weaknesses impact the effective relationships between professionals and users/ family, as well as conducting a practice that is congruent with the vulnerability situations' reality experienced by quilombolas.

There are many distances experienced by the quilombola population in terms of knowledge about the health conditions of these communities, as well as access to health in a comprehensive, equitable and universal way ${ }^{(2,10,19-21)}$. This reality is convergent with a large part of family health in the different Brazilian municipalities ${ }^{(21-23)}$.

Assuming that the constitutional prerogative of equity through which unequal people need to be treated unequally ${ }^{(24)}$, it is possible to perceive that health care in quilombola communities has suffered in an enhanced way. They accumulate the structural weaknesses of the system with the vulnerabilities that accompany the historical trajectory of formation as a community. In relation to the vulnerabilities that characterize quilombola communities and which are accentuated by weaknesses in health care, the following stand out: racial discrimination; extreme poverty; territorial invasions; migration to large urban centers; interference in culture and environmental balance; low rate of household income and informal employment; precarious housing conditions, difficulty in accessing health and education, durable and consumer goods and information; food vulnerability; institutional conflicts; invisibility of the population ${ }^{(21-23)}$.

The low socioeconomic level of quilombola communities restricts access to information and health care, exposes the group to conditions that can affect lifestyle and negatively influences the individual's health status ${ }^{(10)}$. Other studies indicate that socioeconomic factors associated with the high prevalence of risk factors for chronic non-communicable diseases significantly interfere with inequities related to skin color and the historical exclusion of quilombola communities ${ }^{(25-27)}$.

Regarding nurses' practices, in the daily routine of family health in the quilombola communities studied, it is possible to perceive the accumulation of activities and the overlapping of attributions that distance nurses from the effective meeting with users/families. Professionals need to be immersed in the reality of the population, in order to consider the values and experiences of the community's way of life, to reflect on their performance and, more intensely, they need to do it in a critical and responsible manner. This will impact actions that can free the community from the determinant condition of existing social vulnerability ${ }^{(11,28-29)}$.

It is inferred that the development of the relational aspect of nurses' practices is a fundamental component in the care to mitigate the situations of social vulnerability experienced, as well as the inequalities related to access to health. For this, it is necessary to bring the legitimate voice of the other to the spaces of health practice, in listening and making joint decisions, strengthening the care provided by nurses, placing them as powerful emancipatory telos ${ }^{(1,11)}$.

It is, therefore, about the development of political and cultural competence through nurses' practices. Political competence redraws the boundary between moral and political aspects in understanding the social context, as well as in creating bonds, generating subject autonomy in shared decision-making through expressive collaboration (expressive-collaborative) ${ }^{(11)}$.

Cultural competence contributes to improving the quality of health care and access to health services, reducing health disparities between minorities and the hegemonic population, being built on the knowledge of others ${ }^{(12)}$. For this, it requires the need to improve communication between professional and user, culminating in the elimination of structural barriers and in the elaboration of policies that can organize health services appropriately, considering the population's values and culture.

Nurses' practice is configured by rules, laws, attitudes and knowledge in order to be socially recognized and strengthened in social commitment, the relationship between professionals and patients is crucial ${ }^{(30)}$. Therefore, it is essential to configure a practice that respects differences and similarities, that recognizes cultural values and beliefs in order to provide culturally congruent, comprehensive and competent care for people from different cultures ${ }^{(12)}$, promoting a practice liberating and in line with SUS principles.

Nursing care is produced from technical and relational knowledge that can lead to responses to individuals and communities, guided by SUS principles, provides the reduction of vulnerabilities ${ }^{(1)}$. The practice of care based on cultural and political competences has a creative character, with respect for the knowledge, values and experiences of others, enhancing the emancipatory actions and freedom of both scientific and empirical knowledge ${ }^{(29)}$.

In this context, the practice needs to be concretized in the encounter between professional-user so that the relationship provides the clues for the professional to carry out a care plan consistent with the needs of the individual/family/community ${ }^{(2)}$. The daily lives of nurses in health units, especially at FHS, are permeated by the social relationships that the various actors maintain among themselves and must be based on dialogue, listening and the exchange of knowledge, promoting a relationship of trust and social responsibility.

The relationship of trust is the basis for creating a bond. When it is effective, it is possible to continue health actions ${ }^{(2)}$ in a collective construction process between professional, user and team (expressive-collaborative), in which the moral, political and social responsibilities of each are shared, thus reducing forms of oppression ${ }^{(11)}$. Nurses' political positioning contributes to the performance of the bond with the population, in the constant search for the elimination of forms of oppression, of manipulative power of hierarchical and hegemonic groups and of domination of one group over another ${ }^{(11)}$. Nurses' practice must adapt to the realities of a society and care must be realized together with the population through shared moral, political and social actions and responsibilities ${ }^{(11)}$, with a lens for comprehensiveness and equity.

Understanding the social and cultural context with attention to the fragile situations that make up the economic, historical and 
socio-cultural reality is to commit to maintaining and continuing the well-being of an individual/family/community ${ }^{(11)}$. In this way, the nurse's practice is based on moral, cultural and political traits to meet the principles and strengthen SUS.

\section{Study limitations}

This study was limited to data collection settings in quilombola communities in the $\mathrm{RMBH}$, so further investigations need to be carried out to explore other locations. Although the case study allows the deepening of the analyzed phenomenon, its generalization is not possible, considering the sample limitation. However, an analytical generalization is possible, and it is important to reflect on the theoretical contribution of feminist ethics and its implication in questioning the position of social and moral agents and their representativeness within a particular society. Particular attention should be paid to the use of feminist theory in specific contexts and groups that require an approach focused on subjective aspects and with a focus on entangled morality in social knowledge. Thus, researchers should pay attention to the option for this theoretical approach in situations where there is no real applicability.

\section{Contributions to nursing, health and public policies}

This research can contribute to knowledge deepening of nurses' practice in quilombola communities to act in line with the population's health conditions. It is also emphasized the importance of this deepening for carrying out collective actions aimed at achieving SUS principles and guidelines, as well as specific policies aimed at serving the black population. By understanding the importance of nurses' practices in this setting, this study can contribute to scientific development in the field of nursing.

\section{FINAL CONSIDERATIONS}

The present study points out the challenges for the consolidation of SUS within the scope of FHS, after its almost 30 years of creation. It was noticed that the actions of disease prevention and health promotion still have weaknesses. Inadequate infrastructure and work overload affect daily life in health units, compromising the development of practices based on cultural and political competences.

Public policies do not reach the reality of the population, mainly of quilombolas in rural areas. There is a need for real inclusion of quilombolas in decision making in order to build solid relationships, committed to the transformation of a society. The quilombola community is the result of history, presenting in continuous elaboration, emphasizing Afro-descent, in the constant struggle and perpetuation of its own culture intertwined by kinship ties.

In this context, it is necessary that FHS nurses, based on political and cultural training and in conjunction with the team, outline strategies that minimize the difficulties encountered in implementing health actions for this population. These strategies must be anchored in inclusive public policies, especially those aimed at socially vulnerable groups. Furthermore, an attentive look at the formation of a historical awareness of respect for cultures and the way of life is important.

It is known that there are limits to be overcome, especially the hegemonic process of cultural massification in which it disregards Brazilian cultural diversity and imposes a unique culture, contradicting the right to be and live in society. In addition to undermining constitutional principles, such as comprehensiveness, equity and universality, which is crucial for vulnerable communities in terms of access to health.

The literature presents weaknesses in the discussion of this theme, especially with regard to the discussion of the nurse's practice with the Feminist Ethics as an epistemological reference. This theory allows the understanding of the vulnerability context as a potential for the development of transformative practices of daily life. In this sense, other theoretical-methodological approaches that enrich scientific production on quilombola communities become important, contributing to the creation and strengthening of public policies congruent with the reality currently present in Brazil and socially transforming practices.

\section{FUNDING/ACKNOWLEDGMENT}

We would like to thank CNPq, PPSUS, FAPEMIG, CAPES for funding research and scholarship. To the families of quilombola communities and to the professional nurses, who are fundamental for the execution of this study.

\section{REFERENCES}

1. Ayres JRCM. Cuidado: trabalho, interação e saber nas práticas de saúde. Rev Baiana Enferm [Internet]. 2017 [cited 2019 May 07];31(1):e21847. Available from: https://portalseer.ufba.br/index.php/enfermagem/article/view/21847/14115

2. Barbiani R, Nora CRD, Schaefer R. Nursing practices in the primary health care context: a scoping review. Rev Latino-Am Enferm. 2016; 24(e2721):1-12. doi: 10.1590/1518-8345.0880.2721

3. Kahl C, Meirelles BHS, Cunha KS, Bernardo MS, Erdmann AL. Contributions of the nurse's clinical practice to Primary Care. Rev Bras Enferm. 2019;72(2):354-359. doi: 10.1590/0034-7167-2018-0348

4. Ministério da Saúde (BR). Portaria n².436, de 21 de setembro de 2017. Aprova a Política Nacional de Atenção Básica, estabelecendo a revisão de diretrizes para a organização da Atenção Básica, no âmbito do Sistema Único de Saúde (SUS). Brasília: Ministério da Saúde; 2017[cited 2018 Oct 16]. Avaliable from: http://bvsms.saude.gov.br/bvs/saudelegis/gm/2017/prt2436_22_09_2017.html

5. Lubini VT, Willrich JQ, Pinheiro GEW, Luciane PK, Mirela FP. Impacts of educational action on health indicators: potentiality and fragilities. Rev Enferm UFPE[Internet]. 2018[cited 2019 Jan 17];12(6):1640-7. Available from: http://pesquisa.bvsalud.org/portal/resource/pt/biblio-982086 
6. Oliveira SKM, Pereira MM, Guimarães ALS, Caldeira AP. Self-perceived health among 'quilombolas' in northern Minas Gerais, Brazil. Ciênc Saúde Coletiva. 2015;20(9):2879-90. doi: 10.1590/1413-81232015209.20342014

7. Almeida MM, Santos MS, Silva FWT. Nursing care in Sickle Cell Disease in the Family Health Strategy. Rev Pesqui: Cuid Fundam [Internet]. 2018;10(1):36-45. doi: 10.9789/2175-5361.2018.v10i1.36-45

8. Instituto Brasileiro de Geografia e Estatística-IBGE. População chega a 205,5 milhões, com menos brancos e mais pardos e pretos [Internet]. 2019[cited 2019 May 07]. Available from: https://agenciadenoticias.ibge.gov.br/agencia-noticias/2012-agencia-de-noticias/ noticias/18282-populacao-chega-a-205-5-milhoes-com-menos-brancos-e-mais-pardos-e-pretos

9. Fiorio NM, Flor LS, Padilha M, Castro DS, Molina MCB. Mortality by race/color: evidence of social inequalities in Vitória (ES), Brazil. Rev Bras Epidemiol. 2011;14(3):522-30. doi: 10.1590/S1415-790×2011000300016

10. Bezerra VM, Andrade ACS, Medeiros DS, Caiaffa WT. Arterial prehypertension in slave-descendant communities in southeast Bahia State, Brazil. Cad Saúde Pública. 2017;33(10):e00139516 doi: 10.1590/0102-311x00139516.

11. Walker MU. Moral understandings: a feminist study in ethics. Routledge, New York, 1998.

12. Leininger M. Caring for the culturally different necessitates transcultural nursing knowledge and competences. Cultura de los Cuidados, $2^{\circ}$ Semestre, Año III - n.6, 1999.

13. Helman CG. Cultura, saúde e doença. 5a edição, Porto Alegre: Artmed, 2009, p.432.

14. Minayo MCS. O desafio do conhecimento: pesquisa qualitativa em saúde. 14. ed. São Paulo: Hucitec, 2013. 408p.

15. Yin RK. Estudo de caso. Planejamento e métodos. 5ed. Porto Alegre (RS): Bookman. 290 p. 2015.

16. Cortina A. Cidadãos do mundo: para uma teoria da cidadania. São Paulo: Edições Loyola, 2005, 210p.

17. Bardin L. Análise de conteúdo. Edição Revista e Atualizada. Lisboa: Edições 70, 2011

18. Brito MJM, Caram CS, Montenegro LC, Rezende LC, Rennó HMS, Ramos FRS. Potentialities of Atlas.ti for Data Analysis in Qualitative Research in Nursing. In: Costa AP, Reis LPR, Sousa FN, Moreira A, Lamas D (editors) Computer Supported Qualitative Research. Studies in Systems, Decision and Control, v. 71. Switzerland: Springer. 2016. 75-84p. doi: 10.1007/978-3-319-43271-7_7

19. Chor D, Lima CRA. Health inequalities in Brazil: race matters. Cad Saúde Pública. 2013;29(7):1272-5. doi: 10.1590/S0102-311X2013000700002

20. Volochko A, Vidal NP. Racial inequalities in health: mortality in São Paulo State Health Regions. 2005 BIS, Bol Inst Saúde (Impr.) [Internet]. 2010[cited 2018 Nov 19];12(2):143-53. Available from: http://periodicos.ses.sp.bvs.br/scielo. php?script=sci_arttext\&pid=S1518-18122010000200008\&lng=pt

21. Franchi EPLP, Terra MF, Nascimento-Rocha JM, Marquezan RF, Odorizzi VF. The training of health care professionals in the care of the quilombolas communities: a report of experience. Rev Bras Med Fam Comunidade. 2018;13(40):1-11. doi: 10.5712/rbmfc13(40)1620

22. Cabral-Miranda G, Dattoli VCC, Dias-Lima A. Enteroparasitos Condições Socioeconômicas e sanitárias em uma comunidade quilombolas do semiárido Baiano. Rev Patol Trop [Internet]. 2010 [cited 2018 Nov 19];39(1):48-55. Available from: https://www.revistas.ufg.br/iptsp/article/ view/9498/6574

23. Santos NJS. To be black and woman: dual vulnerability to STD/HIV/AIDS. Saúde Soc. 2016;25(3):602-18. doi: 10.1590/s0104-129020162627

24. Vieira ABD, Monteiro PSM. Quilombola community: analysis of the persistent problem in health attention under the focus of the Intervention Bioethics. Saúde em Debate. 2013;37(99):610-8. doi: 10.1590/S0103-11042013000400008

25. Garrafa V. Inclusão social no contexto político da bioética. Rev Brasil Bioética. 2005[cited 2018 Jan18];1(2):122-132. Available from: http:// repositorio.unb.br/handle/10482/25182

26. Ferreira HS, Silva WO, Santos EA, Bezerra MKA, Silva BCV, Horta BL. Body composition and hypertension: a comparative study involving women from maroon communities and from the general population of Alagoas State, Brazil. Rev Nutr[Internet]. 2013;26(5):539-49. doi: $10.1590 /$ S1415-52732013000500005

27. Barroso SM, Melo AP, Guimarães MDC. Factors associated with depression: sex differences between residents of Quilombo communities. Rev Bras Epidemiol[Internet]. 2015;18(2):503-14. doi: 10.1590/1980-5497201500020017

28. Oliveira SKM, Caldeira AP. Fatores de risco para doenças crônicas não transmissíveis em quilombolas do norte de Minas Gerais. Cad Saúde Colet[Internet]. 2016;24(4):420-7. doi: 10.1590/1414-462×201600040093

29. Moraes-Partelli AN, Cabral IE. Images of alcohol in the adolescents' life of one quilombola community. Rev Bras Enferm [Internet]. 2019;72(2):468-75. doi: 0.1590/0034-7167-2018-0264

30. Lindemann H. Feminist ethics of care and responsibility. In: Lindemann H. An invitation to feminist Ethics. Editora: McGraw-Hill Humanities/ Social Sciences/Languages; Edição 1;85-104, 2006. 